\title{
LISTENING TO THE WIND IN THE TREES: MEANING, INTERPRETATION AND LITERARY THEORY
}

\begin{abstract}
H. du Plooy ${ }^{1}$
ABSTRACT

In this article the literary theories which dominated textual studies during the twentieth century are discussed briefly, indicating the philosophical roots of these theories. The article points out that whereas theories during the greater part of the twentieth century tended to encourage a more "open" approach to meaning and textuality, there are clear indications of a new awareness of textual constraints in the last decade. The point is made that interpreters and translators should be aware of the philosophical implications as well as of the textual constraints in the different forms of textual processing. In conclusion the responsibility of translators and interpreters of religious texts is emphasised.
\end{abstract}

Yet releasement toward things and openness to the mystery never happen of themselves. They do not befall us accidentally. Both flourish only through persistent, courageous thinking.

Heidegger Memorial Address.

\section{INTRODUCTION}

Although this article is a contribution to a discussion on issues of translation, it is not directly concerned with translation as such, but with interpretation and formulation as important aspects of the process of creating a new text in relation to an existing text. Translation requires a wide spectrum of extremely specialised language skills and a thorough knowledge of language(s) as such, but what translators do and the products of translation are influenced or even determined by presuppositions about language and meaning much more strongly than many practitioners are willing to concede. This article will indicate prominent trends in contemporary literary theory in an attempt to draw attention to the complexities of processes of interpretation and formulation. I am not qualified to spell out all the implications of these underlying philosophical and theoretical issues for the prac-

1 Prof. Heilna du Plooy, School for Languages: Afrikaans and Dutch, Potchefstroom University for Christian Higher Education, Potchefstroom. 
tice of translation, but I am convinced that experienced translators will be able to weigh the information and find the right slot for it within their own field of expertise.

Approaching the complexities of translation from a literary theoretical angle makes sense when one keeps in mind that literature is regarded as the most complex form of language usage incorporating much more than semiotic meaning or signification. In poetic language all the aspects and possibilities of language are deliberately exploited to concentrate meaning, to achieve that density of meaning which Jurij Lotman (1972:213) saw as the essence of the artistic text when he coined the phrase "Schönheit ist Information".

This article focuses on some prominent trends in contemporary literary theory which have impacted on linguistic practices, but what has to be kept in mind is that theories of literature

can only be understood adequately if they are considered within the philosophical and aesthetic context in which they originated and evolved (Zima 1999:vii).

The central issue guiding the argument through the theoretical and philosophical labyrinth, is the question of the relativity of meaning, that is the indeterminate nature of the meaning of words. Words, sentences and texts contain open areas, blank spaces which have to be filled by interpreters, analysts, critics and translators in the construction of meaning and this construction of meaning is determined by philosophical and theoretical presuppositions. What is considered of paramount importance in this article is the view that on account of the relativity of meaning, language practitioners such as we all are, should be aware of the implications of what we are doing so that we can become more sensitive in our interactions with texts.

The argument rests on the assumption that translators interpret texts and reformulate the meaning they find in those texts so that new texts come into existence. Though excellent work has been and is still being done by interpreters and translators it would perhaps be wise to keep in mind the chastising words of the American poet Robert Frost, who said: "Poetry is what is lost in translation. It is also what is lost in interpretation".

\section{THE OPENING UP OF MEANING}

During the twentieth century literary theories were intensely concerned with the meaning of texts and textual theories and sophisticated reading strategies were developed. The most conspicuous trend in twentieth century literary theory, however, is the increasing "freedom" and rights of the reader. 
This trend can be traced by referring to three prominent strands in theoretical thinking.

2.1 The first half of the twentieth century is dominated by the socalled intrinsic literary theories, also described as the immanent or autonomous theories in which the text is regarded as a monument, fixed and complete and perfect in itself. Nothing should be added to it, neither should or could anything be taken away from it. It so to speak contains itself and is perfect unto itself. The biography of the author, the taste of the reader or interpreter and the contexts of either writing or reading are supposed to be of no importance. These theories do, however, emphasise the aesthetic and textual nature of (especially literary) texts and indicate the importance of concepts such as ambiguity and polivalence. Structural and aesthetic complexities are analysed with great care, but the central idea is that texts should be read for their own sake and not as historical, social, biographical or moral documents.

Anglo-American New Criticism and British close reading or practical analysis (Wimsatt and Beardsley 1992a (1946); Wimsatt and Beardsley 1992b (1948); Brooks 1992 (1947)) belong to this category of theories as well as Russian Formalism (Shklovsky 1992 (1917)), the German immanente Methode (Kayser 1971) and early Czech Structuralism (Mukarovsky 1964). These theories did indeed impact very strongly on teaching and on textual practices in general between (roughly speaking) 1910 and 1960. It can be proved fairly easily that these approaches strongly influenced Biblical studies as well. The contribution of these theories lay in their ideals of scientific rigour as well as in the fact that the professional approach to analysis and interpretation uplifted and improved the level of competence and sophistication in textual practices greatly during this period.

Though this approach was used for all types of texts in the twentieth century, the attitudes expressed in these theories derive from the philosophical position of Immanuel Kant (1924-1804), who is primarily associated with the idea of artistic autonomy. Whether his ideas about purposiveness without purpose (Zweckmässigkeit obne Zweck) are compatible with the nature and functions of mythological or religious texts, is a question which theologians will have to answer. That there is a close relation between artistic and religious texts cannot be denied and therefore the literary aspects of mythological texts is an issue which has to be addressed constantly. For Kant beauty and the experience of beauty (and I wonder whether one could here in very careful way, for argument's sake, substitute faith for beauty) cannot be limited to conceptual thought, because the indeterminate expe- 
rience of beauty cannot adequately be contained in thought or expressed in language (Kant 1987:45-46; Zima 1999:1-5; Du Plooy 2000:8-9).

In artistic texts some of the most essential aspects of meaning in a broad sense do not reside in specific words or phrases, but in subtle interactions between the semantic, syntactic, phonic and rhythmic patterns and metaphoric allusions. This would then also be true for large parts of the Bible and other mythological texts, emphasising the complexity of interpreting and reformulating the content of a text in processes of translation.

2.2 The Kantian views are strongly repudiated by Wilhelm Friedrich Hegel (1770-1831) who considers art and texts "within the perspective of the producer or artist who ... articulates a particular historical consciousness: the consciousness of his time" (Zima 1999:6). According to Hegel (1992:9 (1835)) "clarity" in meaning is possible because there is a correspondence between material form and conceptual content, which implies the possibility of monosemic or univocal meaning. Hegel focuses on the conceptual plane of texts to such an extent that he makes the following remark about poetry:

(i)t is a matter of indifference whether we read it or hear it read; it can even be translated into other languages without essential detriment of its value ... (Zima 1999:7).

From this follows that the textual or expression plane of linguistic texts does not affect the way in which the texts contain or generate meaning because meaning is seen as an accessible social construct.

The theoretical heritage of Hegel can be found in the work of Marxist theorists such as Georg Lukàcs and Lucien Goldman. Their contributions do indeed indicate the importance of linking texts to a reconstructable (or constructed) reality and of emphasising the social and historical relevance of texts, but their approach was called logocentric by Adorno (1992 (1955)) and was opposed strongly by people working in the Kantian tradition as well as by the deconstructionists (Zima 1999:9). Some forms of literature such as fantasy do not fit into this pattern of thinking and the idea that a text could call forth faith or have metaphysical meaning would be rather difficult to accommodate as well.

2.3 The third theoretical strand comes from the Romantic tradition in which philosophers like Schelling and Schlegel defied the rationalist view that art should have a didactic function. They stress the dark side of language, its irreducible polysemy, its resistance to clear and adequate interpretation and its hermetic tendencies which dominate especially in artistic texts. The expression plane of texts, incorporating structure, syntax, 
sound and metaphor, complicates the semiotic or straightforward semantic content in such a way that meaning seems to shift incessantly and becomes obscure (Du Plooy 2000:11).

This position is radicalised by Friedrich Nietzsche who on account of the instability of texts, not only questions the status of texts but also the conceptual frameworks underlying the texts. According to Nietzsche all interpretation and meaning and especially value systems are informed by conceptual frameworks which are generated and sustained in and through language. He reveals the ambivalent and contradictory character of the key values of Western civilisation by exposing the fallibility of the linguistic nature of the metaphysical base or framework behind the value system. He asks: "What, then, is truth? ... a mobile army of metaphors, metonymies, and other rhetorical figures" (Nietzsche 1992:636). He uses the ambiguity and instability of the rhetorical aspects of language to undermine the conceptual systems which inform texts and interpretations alike and his project is especially directed at demolishing the metaphysical edifice, in particular the concept of truth in Western thought (Zima 1999:140-147).

The instability of the linguistic sign is formalised by developments in linguistics early in the twentieth century. Ferdinand de Saussure's notion of the arbitrariness and the polysemic possibilities of the linguistic sign has had far-reaching consequences. Though De Saussure does indicate the importance of codes or conventions to link the signifier to a signified, the gap between the two aspects of the sign has become the focus of ensuing linguistic and literary theories. Where the Structuralists analysed texts as manifestations of the master pattern of language (by theoreticians such as Bremond, Greimas and Todorov — Du Plooy 1986:162-192), the semioticians (like Lotman, Mukarovsky, Doležel and Eco - Du Plooy 1986:125-143; 239-255) concentrated on the codes, codification and strategies of encoding and decoding. The distinction between the text as an artefact or material object on the one hand and as an interpreted aesthetic object on the other (proposed by Czech Structuralists and linked to De Saussure's distinction between signifier and signified), also opens up the way for the development of the reader-response criticism of Hans Robert Jauss and Wolfgang Iser of the Constance School (Iser 1974). In this approach meaning does not reside in the text but in the perceptions and reactions of the reader (Freund 1987).

The greatest impact on the scene of literary theory in the last part of the twentieth century is effected by deconstruction, by people such as Roland Barthes and Jacques Derrida in France and the Yale deconstructionists in the USA (sometimes referred to as the Yale mafia, J. Hillis Miller, Harold Bloom, Geoffrey Hartman and Paul de Man). According to Barthes (1975) 
linguistic signs or signifiers are polysemic to the extent that they are unable to represent conceptual systems and Derrida (1992 (1966)) and the Yale deconstructionists refuse to accept the existence of any conceptual systems. In the same way as Nietzsche, they argue that all systems are reliant on language to exist and linguistic instability then renders the project impossible. Because the linguistic text can be deconstructed and because its meaning can be radically questioned and undermined, there is no way in which underlying concepts can exist or be communicated (Zima 1999:140-160).

These theoretical developments have had an extensive influence on practices of interpretation and on the way in which people regarded language during the last two decades of the twentieth century. One can see some of the positions as reactions against approaches which allowed too little scope for interpretations, but the overall impression is one of loosening up, of allowing greater freedom to the individual reader or interpreter. That this was necessary and that it stimulated creativity in reading is generally accepted. T. S. Eliot once remarked:

About anyone so great as Shakespeare, it is possible that we can never be right, and if we can never be right, it is better that we should from time to time change our way of being wrong (Felperin 1985:147).

How much more true would this not be for the Bible. And indeed all the free and creative interpretations and translations of texts, including the Bible, bear ample indication of the freedom of textual play. But to think that everything goes, would be absolutely simplistic, as I assume every responsible interpreter and translator knows only too well.

\section{THE LIMITS AND CONSTRAINTS OF INTERPRETATION}

Where the greater part of the twentieth century was devoted to a process of opening up meaning, a process which focussed mainly on the democratic rights of the reader and the importance of the context, the extremity to which these debates brought the textual industry, has led to serious doubts and misgivings about the implications and consequences of the implementation of some of these theories in practice. It seems that there are now numerous theoreticians and interpreters who feel that it is imperative to once again take cognisance of the limitations of meaning. This has inevitably lead to a need to redefine the status of the text as text. 
Building on theories such as that of Bakhtin (Dentith 1995) and even that of Julia Kristeva (1984; Smith 1998) in which textuality and extratextual context are both recognised and accounted for, many theoreticians have over the last two decades been working on theoretical approaches which stimulate creativity while retaining and respecting the status of the text (Pavel 1986; Gould 1981; Zima 1999). The limitations and constraints of interpretation are for instance discussed at length by Umberto Eco in his book The limits of interpretation (1990), the postparadigmatic position of literary theory is analysed by Bradford in The state of theory (1993), while questions about the status of the text are addressed in Harris' Literary meaning — reclaiming the study of literature (1996) and Harrison's Inconvenient fictions - literature and the limits of theory (1991).

In the introduction to his book The limits of interpretation Umberto Eco describes his concern with the limitations and constraints of interpretation. Referring to his earlier work he writes:

When those pages were written, my readers focused mainly on the "open" side of the whole business, underestimating the fact that the open-ended reading I supported was an activity elicited by (and aiming at) a work. In other words, I was studying the dialectics between the rights of texts and the rights of their interpreters. I have the impression that, in the course of the last few decades, the rights of the interpreters have been overstressed. In the present essays I stress the limits of the act of interpretation (Eco 1990:6).

Eco (1990:60) also refers to the fact that even the most radical deconstructionists find some interpretations unacceptable, i.e. in an article from 1980 in Critical Inquiry 6, J. Hillis Miller writes that

the readings of deconstructive criticism are not the wilful imposition by a subjectivity of a theory on the texts, but are coerced by the texts themselves.

In the book Thomas Hardy: distance and desire he writes:

$\ldots$ it is not true that ... all readings are equally valid. Some readings are certainly wrong ... To reveal one aspect of a work of an author often means ignoring or shading other aspects ... Some approaches reach more deeply into the structure of the text than others.

Deconstructionists have therefore not been legitimising any reading but have from the earliest phases of deconstruction been aware of limitations and constraints. Later and less professional followers were much more extreme. 
The problem is how to define these constraints. It is not so easy to find an acceptable position between on the one hand the belief that somewhere in the text there is hidden one single perfectly true meaning and on the other hand the almost scary freedom to do whatever you would like to do with potential meanings and interpretations.

Harrison explains how language does much more than referring to or representing reality or recognisable aspects of material reality, because of the complexity of the subtle workings of the textual mechanisms and their influence on people, but he also emphasises that these processes are limited. About interpretation and textual practices, he writes: "It is an art of limitations: the knowledge it offers is knowledge of limits and limitations: ours" (Harrison 1991:6).

What is also important to realise is that the contemporary theoretical scene is influenced not only by remnants of all the literary and linguistic theories mentioned above, but by approaches whose scope reaches into the realms of society, politics and culture insofar as they explain textual and aesthetic concepts and interpretations within particular historical, political and cultural frameworks. The impact of cultural studies, postcolonial studies, New Historicism and feminism on all textual practices is very strong. These approaches ask differing sets of questions, questions such as: How does a particular text fit into a particular cultural or historical context? How can cultural or social patterns in texts or the text itself as a product be explained within power structures which are economically, socially or politically sanctioned? Do women read differently from men or what can be deduced from a text about the position of women in society? The answers to these questions may differ radically from time to time and may provide different interpretations of the same text at different moments in history. In such discourses the introduction of new power relations on account of the pragmatic demands of political or social situations (which also impact on interpretation or translation in various ways), may and do also occur frequently and interpreters and translators should be aware of this.

\section{TRANSLATION}

The variety of possibilities and methodologies complicate the act of interpretation, but even more so the work of the translator. Whereas interpretations are more short-lived, the translation of a text may be the only access to that text for the users of the goal language and as such translations have longer lives and even get assigned canonical status. The responsibility of the translator of religious texts is therefore enormous. In keeping with the 
constraints which have been referred to above, a few points could be made about the practice of interpretation and translation from the angle of literary theory.

While keeping in mind the open-ended character of language by accepting that no interpretation can be absolutely correct, the interpretertranslator is in the first instance confronted by the inevitable textual aspects of a text, the phonetic, semantic, syntactic and narrative structures, the specific metaphoric style and a specific linguistic register which cannot be denied. These aspects of a text have to be recognised as meaningful in themselves so that interpretation is not completely arbitrary but permanently and irrevocably guided by the determinants of the original text. Whereas interpretations in classrooms and in literary essays and papers at conferences attempt to impress people with their creativity in producing exceptionally original or radical readings of texts, the translator does not enjoy that much freedom. He does not have ownership of the text, he has to respect the limitations imposed upon him by the text itself. Umberto Eco (1990) describes his view as follows:

A text is a place where the irreducable polysemy of symbols is in fact reduced because in a text symbols are anchored to their context ... thus many modern theories are unable to recognise that symbols are paradigmatically open to infinite meanings but syntagmatically, that is, textually, open to the indefinite, but by no means infinite, interpretations allowed by the context.

I have come to realise that when one accepts the fact that texts are riddled with open places and spaces, that the meaning of every word is obscured by the complexities of codification and association inherent in the arbitrary nature of the linguistic sign, one cannot only use the freedom for play (as is sometimes suggested) but one has to take responsibility for that which you insert into the empty areas of meaning. When textual practitioners in whichever field of expertise call on literary theories to justify their methods and views, they should make sure that they understand the full implications of the ideas they buy and of the methods they use. Texts function in specific domains and apart from the textual textures and the intratextual contexts, the type of text and the type of communication have to be considered carefully as well before too many freedoms are taken in interpretation and translation.

Translation or interpretation cannot be the same as writing a review of the text. Intertextual explorations of existing texts, testing the limits or expanding the scope of the meanings of a text may be a wonderful creative exercise where fictional texts are concerned, but should the followers of a 
specific religion be expected to grant to such explorations or experiments or interpretative playfulness by textprocessors of religious texts the same status as the original text?

The final responsibility for what is inserted into the open places in texts lies with the interpreter and that is an enormous responsibility where religious texts are concerned. If the interpreter is an atheist, he would not fill the open places in Biblical texts with religious content, he would not be able to interpret that which points to faith. In the same way that a psychologically disturbed person reads his own psychosis into a text, all readers read themselves into the texts before them if they allow themselves to freely follow their natural inclinations, if they do not exert themselves to verify their interpretations through comparison and thorough study of all relevant textual and extratextual contexts. This can be done and has been done extensively in the case of Biblical translation with its a long and worthy tradition.

When people ask radical questions about those parts or aspects of the Bible which are not absolutely scientifically and rationally clear, I cannot help thinking that they are revealing more about themselves than about the texts they are dealing with. Texts which are concerned with the mysteries behind the surfaces of reality, need to be read with a keen eye for specifically the gap between signifier and signified, because this is where, according to Eric Gould (1981), the numinous resides.

\section{FORMULATION}

Added to the intricate requirements of interpretation the translator has to formulate his results. A mistake or inaccuracy which pushes interpretation into a certain direction, can be aggravated if the formulation moves even further in the same direction. In any case formulation is not an easy task. All creative writers are always struggling with words. Words themselves are ethereal, they are deceptive, they indeed have a dark side which harbours reflections and echoes from far and wide. Choosing words is indeed a dangerous undertaking, the more so because words carry an incalculable and unpredictable amount of intertextual baggage. The translator is caught between two fires, between interpretation and formulation, and he cannot escape the heat because he needs them both.

It does seem to me that a translator has a meticulous and rather conservative task to fulfil. While working on the new rhymed version of the Psalms we time and again realised how difficult it was to work with metaphors in the transformations of texts. If you explain or change a metaphor, you actually reduce its original scope. You are most probably taking only 
one of the many associations and meanings that the metaphor conjures up and canonise that one as the only or as the ultimate meaning. The Afrikaans Bible translation of 1983 contains much explanation, but the poetic parts of the Biblical text have consequently been impoverished in comparison to the old translation or to the original.

There are other examples as well. Writers often have a special feeling for sentences, experimenting to see what can be achieved with sentence structure in terms of generating meaning. I therefore think that it is quite possible that Paul used long sentences in his epistles not because of an inability to write well, but because the sentence structure may be meaningful in itself. A long sentence may for instance iconically suggest the infinite flow of faith. Does one then have the right to rewrite Paul's meanings into clear and neatly clipped little sentences? The same goes for the long introductory sentence at the beginning or the Epistle to the Ephesians which may have an added iconic meaning by referring to the Trinity of God in one sentence. The same goes for incomplete sentences such as in Romans 8:1 \& 2 . One should keep asking: does only the semantic value of the words generate meaning or is the sentence structure as such also meaningful?

Recently a colleague, who is an experienced translator, translated a short story by P. G. du Plessis, which was to be used in a paper at an international conference. The translation contained all the information of the original story and was absolutely well formulated. When the author looked at the translation, he said nothing but he went home and rewrote the whole story. Afterwards he said that the translation had lost the rhythm and that the rhythm was the most important aspect of the story. Though this example refers to literary translation which is a specific type of translation, the process remains the same and I cannot see that the Bible can stylistically be regarded as anything but a literary text.

\section{CONCLUSION}

The translation of the Bible must be one of the most taxing tasks that can be undertaken. Every translation will moreover inevitably bear witness to the historical period in which it is undertaken and to the stylistic preferences of the translator(s). The most difficult thing is to hear or to determine or to sense the meanings hidden in the open spaces of the words and the text itself without desecrating the text.

I have taken the title for this article from the novel Woordwerk by Breyten Breytenbach. The narrator in the novel is intensely aware of the indeterminate nature of language and feels as if he himself is defeated by an 
attempt to indicate the ultimate meaning of what he has written. He then advises the reader: "Miskien moet jy maar net luister vir die afwesighede tussen fragmente, vir wind in die bome" (Perhaps one should listen for the gaps between fragments, for the wind in the trees). But experience has taught us that there are indeed interpreters and translators who are excellent listeners, even to the wind.

\section{BIBLIOGRAPHY}

ADAms H (ed.)

1992. Critical theory since Plato. Fort Worth/Philadelphia: Harcourt Brace Jovanovich College Publishers.

\section{ADORNO T}

1992 (1955). Cultural criticism and society. In: Adams (ed.) 1992:1033-1040.

\section{BARTHES R}

1975. S/Z. London: Jonathan Cape.

BRADFORD R (ed.)

1993. The state of theory. London: Routledge.

\section{BREYTENBACH B}

1999. Woordwerk. Kaapstad: Human \& Rousseau.

\section{BroOKs C}

1992 (1947). The heresy of paraphrase. In: Adams (ed.) 1992:961-967.

\section{DENTITH S}

1995. Bakbtinian thought. London: Routledge.

\section{DERRIDA J}

1992 (1966). Structure, sign and play in the discourse of the human sciences. In: Adams (ed.) 1992:1117-1126.

\section{Du PloOY H}

1986. Verhaalteorie in die twintigste eeu. Durban: Butterworth.

2000. Die beduidende leegtes van die literatuur. Wetenskaplike bydraes, Reeks H: Inougurele rede nr. 166. Potchefstroom: PU vir $\mathrm{CHO}$.

\section{ECO U}

1990. The limits of interpretation. Bloomington: Indiana University Press. 


\section{FELPERIN H}

1985. Beyond deconstruction. New York: Oxford University Press.

\section{FREUND E}

1987. The return of the reader: reader-response criticism. London: Methuen.

GARVIN P L (ed.)

1964. A Prague school reader on esthetics, literary structure and style. Washington,

D.C.: Georgetown University Press.

GOULD E

1981. Mythical intentions in modern literature. Princeton, N.J.: Princeton University Press.

\section{HARRIS W V}

1996. Literary meaning. Reclaiming the study of literature. London: Macmillan.

\section{HARRISON B}

1991. Inconvenient fictions. London: Yale University Press.

\section{HEGEL G W F}

1992 (1835). The philosophy of fine art (extract). In: Adams (ed.) 1992:534544.

\section{ISER W}

1974. The implied reader. Baltimore: The Johns Hopkins University Press.

\section{KANT I}

1992 (1790). Critique of judgement (extracts). In: Adams (ed.) 1992:376-393.

\section{KAYSER W}

1971. Das sprachliche Kunstwerk. Bern: Francke.

\section{KRISTEVA J}

1984. Revolution in poetic language. A semiotic approach to literature and art. New York: Columbia University Press.

\section{LOTMAN J M}

1972. Die Struktur literarischer Texte. Übersetzt von Rolf-Dietrich Keil. München: Fink Verlag.

\section{Mukarovsky J}

1964. Standard language and poetic language. In: Garvin (ed.) 1964:17-30.

\section{NiETZSCHE F}

1992 (1873). Truth and falsity in an ultramoral sense. In: Adams (ed.) 1992: 624-639.

\section{PAVEL T}

1986. Fictional worlds. Cambridge, Mass.: Harvard University Press. 


\section{SHKLOVSKY V}

1992 (1917). Art as technique. In: Adams (ed.) 1992:751-759.

\section{SMITH A-M}

1998. Julia Kristeva - speaking the unspeakable (Modern European thinkers). London: Pluto Press.

WiMSATT W K \& BEARDSLEY M C

1992a (1946). The intentional fallacy. In: Adams (ed.) 1992:945-951.

1992b (1948). The affective fallacy. In: Adams (ed.)1992:952-959.

ZIMA P V

1999. The philosophy of modern literary theory. New Brunswick: The Athlone Press.

Keywords

Literary theories

Twentieth century

Textual constraints

Translation 